\title{
Two New Diterpenoids from Thuja orientalis and Their Cytotoxicity
}

\author{
Chung Sub Kim, Won Se Suh, Sang Un Choi, ${ }^{\dagger}$ Ki Hyun Kim, and Kang Ro Lee* \\ Natural Products Laboratory, School of Pharmacy, Sungkyunkwan University, Suwon 440-746, Korea \\ *E-mail: krlee@skku.edu \\ ${ }^{\dagger}$ Korea Research Institute of Chemical Technology, Daejeon 305-343, Korea \\ Received March 28, 2014, Accepted May 19, 2014
}

Key Words : Thuja orientalis, Cupressaceae, Diterpenoid, Cytotoxicity

Thuja orientalis L. [= Biota orientalis (L.) Endl., Platycladus orientalis (L.) Franco] (Cupressaceae) is an evergreen arbor widely distributed throughout Korea and China. This plant has been used in the traditional medicine for the treatment of hemorrhoids and hypertension. ${ }^{1}$ Previous chemical investigations on this plant reported the isolation of terpenoids, flavonoids and lignans. ${ }^{1-3}$ The extract and some constituents of this plant were reported to exhibit anti-inflammatory, cytotoxic, and neuroprotective activities. ${ }^{3-5}$ We investigated the constituents of the leaves of T. orientalis as part of our continuing search for cytotoxic secondary metabolites from Korean medicinal plants and reported about cytotoxic diterpenoids. ${ }^{6}$ Further we isolated two new stereoisomers (12) and seven known compounds (3-9) (Figure 1). The chemical structures of 1-2 were determined by spectroscopic methods, including $1 \mathrm{D}$ and $2 \mathrm{D} \mathrm{NMR}\left({ }^{1} \mathrm{H}\right.$ and ${ }^{13} \mathrm{C} \mathrm{NMR}$, DEPT, ${ }^{1} \mathrm{H}-{ }^{1} \mathrm{H}$ COSY, HMQC, HMBC, and NOESY). Previously, 3 was reported with incomplete stereochemistry, ${ }^{6}$ and now we reported the complete stereostructure of $\mathbf{3}$. Compounds 1, 2 and 4-9 were evaluated for their cytotoxicity against A549 (non small cell lung adenocarcinoma), SK-OV-3 (ovarian cancer cells), A498 (renal cell carcinoma) and HCT-15 (colon cancer cells) human tumor cell lines using an in vitro sulforhodamine B (SRB) assay.

Compound 1 was obtained as a colorless gum. The molecular formula $\mathrm{C}_{22} \mathrm{H}_{34} \mathrm{O}_{5}$ was determined from the ion peak $[\mathrm{M}+\mathrm{Na}]^{+}$at $\mathrm{m} / z 401.2300$ (calcd for $\mathrm{C}_{22} \mathrm{H}_{34} \mathrm{NaO}_{5}$,
401.2304) in positive ion HRFABMS. The ${ }^{1} \mathrm{H}$ NMR spectrum showed the presence of signals due to three olefinic $[\delta$ $5.65,4.86$, and 4.50 (each brs)], two acetalic $[\delta 5.54$ and 5.42 (each brs)], two methoxyl [ $\delta 3.42$ and 3.38 (each s)], and two tertiary methyl $[\delta 1.23$ and 0.61 (each s)] protons. The ${ }^{13} \mathrm{C}$ NMR spectrum showed 22 carbon signals which were attributed to four methyl, eight methylene, and five methine groups, as well as five quaternary carbons, including one carbonyl carbon $(\delta 182.7)$, four olefinic carbons $(\delta$ $147.8,146.3,123.7$ and 106.7), and two acetalic carbons $(\delta$ 107.9 and 107.1), determined by the analysis of the DEPT and HMQC spectra. These spectroscopic data of $\mathbf{1}$ were closely resembled to those of $3^{6}$ with the exception that $\mathrm{H}$ $12 \mathrm{a}$ and $\mathrm{H}-12 \mathrm{~b}$ signals of $\mathbf{1}$ ( $\delta 2.25$ and 2.02 , respectively) were slightly shifted ( $\delta 2.35$ and 1.88 , respectively, 3 ) in the ${ }^{1} \mathrm{H}$ NMR spectrum, indicating that $\mathbf{1}$ may be a stereoisomer of 3. The planar structure of 1 was confirmed by the DEPT, ${ }^{1} \mathrm{H}-{ }^{1} \mathrm{H}$ COSY, HMQC and HMBC spectra (Figure 2). A trans-fused $\mathrm{A} / \mathrm{B}$ ring junction was inferred from the absence of NOESY correlation of $\mathrm{H}-5 / \mathrm{H}-20$ and the NOESY crosspeaks of $\mathrm{H}-5 / \mathrm{H}-9$ and $\mathrm{H}-18$ and $\mathrm{H}-11 / \mathrm{H}-20$ confirmed the relative stereochemistry at $\mathrm{A}$ and $\mathrm{B}$ rings (Figure 3 ). The $\mathrm{H}-$ $14, \mathrm{H}-15$, and $\mathrm{H}-16$ signals in ${ }^{1} \mathrm{H}$ NMR $(\delta 5.65,5.54$, and 5.42 , respectively) were very similar to those of the cis-form of the 1,4-dihydro-1,4-dimethoxy furan ring ( $\delta 5.64,5.50$ and 5.35), not to those of the trans-form $(\delta 5.80-5.70$ and 5.68-5.60), ${ }^{7,8}$ indicating the $\mathrm{H}-15$ and $\mathrm{H}-16$ of 1 were in the

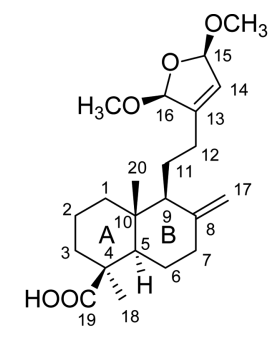

1

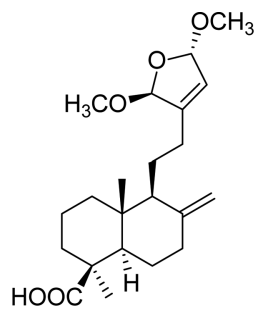

2

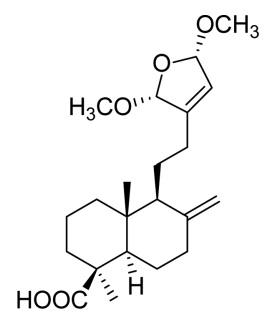

3

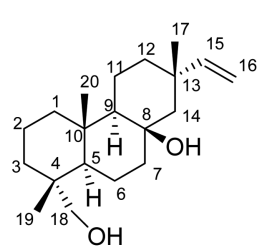

4
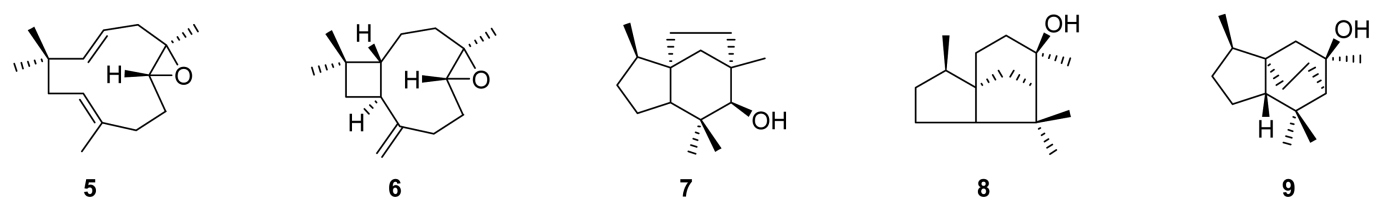

Figure 1. The structures of 1-9 from T. orientalis. 


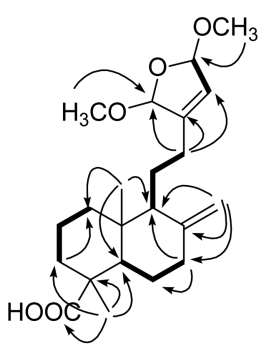

1

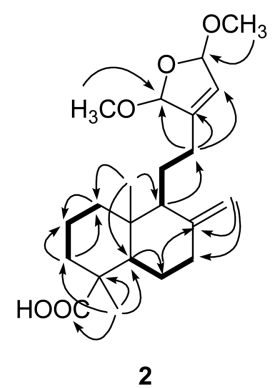

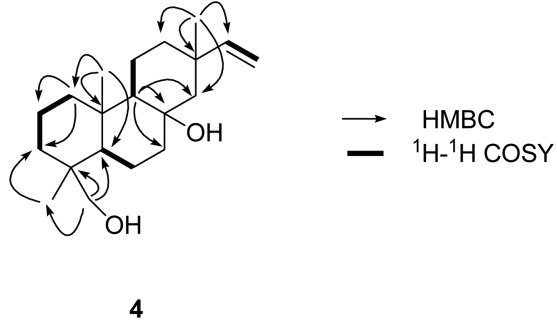

methoxylambertianic acid.

Compound 3 was reported with two methoxyl groups at $\mathrm{C}-15$ and $\mathrm{C}-16$ in the previous paper without the determination of stereochemistry. ${ }^{6}$ In the present paper, $15 \alpha$ and $16 \alpha$ forms of two methoxyl groups were to be confirmed by spectroscopic data. With the H-14, H-15, and $\mathrm{H}-16$ signals in ${ }^{1} \mathrm{H}$ NMR ( $\delta 5.67,5.53$, and 5.40, respectively) was confirmed configurations of $\mathrm{H}-15$ and $\mathrm{H}-16$ are in cis-form. ${ }^{7}$ In the NOESY spectrum, the correlations of $\mathrm{H}-12 \mathrm{a} / \mathrm{H}-17 \mathrm{~b}$ and $\mathrm{H}-12 \mathrm{~b} / \mathrm{H}-16$ showed the same orientation for $\mathrm{H}-12 \mathrm{a}$ and $\mathrm{H}-$ $17 \mathrm{~b}$ as well as for $\mathrm{H}-12 \mathrm{~b}$ and $\mathrm{H}-16$ (Figure 3). Additional NOESY cross-peaks of H-9/H-12a and H-11/H-14 and H-20 confirmed the stereochemical structure of $\mathbf{3}$ again. Thus, the structure of 3 was assigned as $(15 \alpha, 16 \alpha)$-15,16-dihydro15,16-dimethoxylambertianic acid and got the name "thujuoric acid C".

Compound $\mathbf{4}$ was previously isolated from the same plant by BioBioPha Co., Ltd. (Catalog No. BBP01304, CAS No. 73002-86-5) and the structure of $\mathbf{4}$ was confirmed by comparison of its ${ }^{1} \mathrm{H}$ NMR data with those of an authentic company sample. NMR data assignments (Tables 1 and 2) of 4 were performed by analysis of 2D NMR data (HMQC, HMBC, and NOESY). To the best of our knowledge, the full NMR data of $\mathbf{4}$ were reported for the first time in this study.

By comparison of ${ }^{1} \mathrm{H}$ and ${ }^{13} \mathrm{C}$ NMR data and MS spectral data with those in the literatures the structures of compounds 5-9 were determined to be humulene epoxide II (5), ${ }^{11} \beta$ caryophyllene $8 R, 9 R$-oxide (6), ${ }^{12}$ sesquithuriferol (7) ${ }^{13}$ cedrol (8), ${ }^{14} 2,2,6,9$-tetramethyltricyclo[5.2.2.0 $\left.0^{3,7}\right]$ undecan-9-ol (9). ${ }^{15}$

Furthermore the compounds $\mathbf{1}, \mathbf{2}$ and $\mathbf{4 - 9}$ were evaluated for their cytotoxicity against A549, SK-OV-3, A498 and HCT-15 human tumor cell lines with the use of an in vitro $\mathrm{SRB}$ assay. Compound $\mathbf{4}$ showed with $\mathrm{IC}_{50}$ values of 23.17, $31.29,23.96,21.14 \mu \mathrm{M}$ a moderate cytotoxicity against A549, SK-OV-3, A498 and HCT-15 cells, respectively. All other compounds were inactive.

\section{Experimental Section}

General. Optical rotations were obtained on a JASCO P1020 Polarimeter. IR spectra were recorded on a Bruker Vector 22 IR spectrophotometer. NMR spectra, including ${ }^{1} \mathrm{H}-{ }^{1} \mathrm{H}$ COSY, HMQC, HMBC and NOESY experiments, were recorded on a Varian UNITY INOVA 500 NMR spectrometer operating at $500 \mathrm{MHz}\left({ }^{1} \mathrm{H}\right)$ and $125 \mathrm{MHz}\left({ }^{13} \mathrm{C}\right)$. 
Table 1. ${ }^{1} \mathrm{H}$ NMR [ppm, mult $(\mathrm{J}$ in $\left.\mathrm{Hz})\right]$ spectral data of compounds $1-4$ in $\mathrm{CDCl}_{3}(500 \mathrm{MHz})$

\begin{tabular}{|c|c|c|c|c|c|c|}
\hline Position & 1 & & 2 & & 3 & 4 \\
\hline 1a & 1.90 & $\mathrm{~m}$ & 1.87 & $\mathrm{~m}$ & $1.90 \mathrm{~m}$ & $1.72 \mathrm{~m}$ \\
\hline $1 b$ & 1.10 & $\mathrm{~m}$ & 1.10 & $\mathrm{~m}$ & $1.10 \mathrm{~m}$ & $0.84 \mathrm{~m}$ \\
\hline $2 \mathrm{a}$ & 1.86 & $\mathrm{~m}$ & 1.87 & $\mathrm{~m}$ & $1.84 \mathrm{~m}$ & $1.70 \mathrm{~m}$ \\
\hline $2 b$ & 1.54 & $\mathrm{~m}$ & 1.53 & $\mathrm{~m}$ & $1.55 \mathrm{~m}$ & $1.60 \mathrm{~m}$ \\
\hline $3 a$ & 2.17 & brd (11.0) & 2.16 & brd (9.5) & $2.18 \mathrm{~m}$ & $1.42 \mathrm{~m}$ \\
\hline $3 b$ & 1.10 & $\mathrm{~m}$ & 1.06 & $\mathrm{~m}$ & $1.12 \mathrm{~m}$ & $1.25 \mathrm{~m}$ \\
\hline 5 & 1.35 & $\mathrm{~m}$ & 1.34 & $\mathrm{~m}$ & $1.36 \mathrm{~m}$ & $1.20 \mathrm{dd}(12.5,2.0)$ \\
\hline $6 a$ & 2.00 & $\mathrm{~m}$ & 2.00 & $\mathrm{~m}$ & $2.00 \mathrm{~m}$ & $1.51 \mathrm{~m}$ \\
\hline $6 b$ & 1.90 & $\mathrm{~m}$ & 1.90 & $\mathrm{~m}$ & $1.91 \mathrm{~m}$ & $1.42 \mathrm{~m}$ \\
\hline $7 \mathrm{a}$ & 2.42 & brd (9.0) & 2.41 & brd (9.5) & $2.43 \mathrm{~m}$ & $1.63 \mathrm{~m}$ \\
\hline $7 b$ & 1.91 & $\mathrm{~m}$ & 1.89 & $\mathrm{~m}$ & $1.90 \mathrm{~m}$ & $1.40 \mathrm{~m}$ \\
\hline 9 & 1.65 & $\mathrm{~m}$ & 1.64 & $\mathrm{~m}$ & $1.65 \mathrm{~m}$ & 0.91 brs \\
\hline $11 \mathrm{a}$ & 1.77 & $\mathrm{~m}$ & 1.73 & $\mathrm{~m}$ & $1.78 \mathrm{~m}$ & $1.61 \mathrm{~m}$ \\
\hline $11 b$ & 1.59 & $\mathrm{~m}$ & 1.57 & $\mathrm{~m}$ & $1.59 \mathrm{~m}$ & $1.49 \mathrm{~m}$ \\
\hline $12 \mathrm{a}$ & 2.25 & ddd $(15.0,10.5,4.0)$ & 2.28 & $\operatorname{ddd}(15.5,10.0,3.5)$ & $2.35 \mathrm{~m}$ & $1.56 \mathrm{~m}$ \\
\hline $12 b$ & 2.02 & $\mathrm{~m}$ & 2.00 & $\mathrm{~m}$ & $1.88 \mathrm{~m}$ & $1.31 \mathrm{~m}$ \\
\hline $14 \mathrm{a}$ & 5.65 & brs & 5.66 & brs & 5.67 brs & $1.32 \mathrm{~m}$ \\
\hline $14 b$ & & & & & & $1.26 \mathrm{~m}$ \\
\hline 15 & 5.54 & brs & 5.70 & $\mathrm{~d}(2.5)$ & 5.53 brs & $5.71 \mathrm{dd}(17.5,10.5)$ \\
\hline $16 \mathrm{a}$ & 5.42 & brs & 5.80 & $\mathrm{~d}(2.5)$ & 5.40 brs & $4.86 \mathrm{~d}(17.5)$ \\
\hline $16 \mathrm{~b}$ & & & & & & $4.80 \mathrm{~d}(10.5)$ \\
\hline $17 \mathrm{a}$ & 4.86 & brs & 4.86 & brs & 4.86 brs & $1.21 \mathrm{~s}$ \\
\hline $17 \mathrm{~b}$ & 4.50 & brs & 4.50 & brs & $4.51 \mathrm{brs}$ & \\
\hline $18 \mathrm{a}$ & 1.23 & $\mathrm{~s}$ & 1.23 & s & $1.24 \mathrm{~s}$ & $3.42 \mathrm{~d}(10.5)$ \\
\hline $18 \mathrm{~b}$ & & & & & & $3.10 \mathrm{~d}(10.5)$ \\
\hline 19 & & & & & & $0.79 \mathrm{~s}$ \\
\hline 20 & 0.61 & s & 0.61 & s & $0.61 \mathrm{~s}$ & $1.02 \mathrm{~s}$ \\
\hline $15-\mathrm{OCH}_{3}$ & 3.42 & $\mathrm{~s}$ & 3.35 & $\mathrm{~s}$ & $3.42 \mathrm{~s}$ & \\
\hline $16-\mathrm{OCH}_{3}$ & 3.38 & s & 3.41 & s & $3.38 \mathrm{~s}$ & \\
\hline
\end{tabular}

HRFAB and HREI mass spectra were obtained on a JEOL JMS700 mass spectrometer. Preparative HPLC was performed using a Gilson 306 pump with a Shodex refractive index detector. Silica gel 60 (230-400 mesh) and RP-C 18 silica gel (230-400 mesh) were used for the column chromatography. TLC was performed using the precoated Silica gel $\mathrm{F}_{254}$ plates and RP-18 $\mathrm{F}_{254 \mathrm{~s}}$ plates (Merck). Spots were detected on TLC by heating after spraying with $10 \% \mathrm{H}_{2} \mathrm{SO}_{4}$ in EtOH $(\mathrm{v} / \mathrm{v})$.

Plant Material. The leaves of $T$. orientalis were collected in Yeongcheon City, Korea during May 2009. The plant was identified by one of the authors (K. R. Lee). A voucher specimen (SKKU-NPL 0819) of the plant was deposited at the herbarium of the School of Pharmacy at the Sungkyunkwan University in Suwon, Korea.

Extraction and Isolation. An amount of $4 \mathrm{~kg}$ leaves of $T$. orientalis was extracted at room temperature with $80 \% \mathrm{MeOH}$ and evaporated under reduced pressure with $405 \mathrm{~g}$ residue. The residue was dissolved in water $(800 \mathrm{~mL} \times 2)$ and solventpartitioned to $n$-hexane (73 g), $\mathrm{CHCl}_{3}$ (41 g), EtOAc (42 g) and $n$-BuOH (104 g) layers. The $n$-hexane-soluble layer (36 g) was chromatographed on a silica gel column (230-400 mesh, $600 \mathrm{~g}, 5 \times 60 \mathrm{~cm})$ eluted with $n$-hexane:EtOAc $(5: 1 \sim$
$1: 1$, gradient system) to yield four fractions $(\mathrm{H} 1-\mathrm{H} 4)$. Fraction $\mathrm{H} 1$ (3.6 g) was separated over a RP-C 18 silica gel column (230-400 mesh, $150 \mathrm{~g}, 3 \times 30 \mathrm{~cm})$ with $90 \% \mathrm{MeOH}$ to five subfractions (H11-H15). Fraction H13 (620 mg) was separated over a silica gel column (230-400 mesh, $50 \mathrm{~g}, 2 \times$ $25 \mathrm{~cm})$ with $\mathrm{CHCl}_{3}: \mathrm{MeOH}(150: 1)$ and purified with a RP$\mathrm{C}_{18}$ prep. HPLC with $75 \% \mathrm{CH}_{3} \mathrm{CN}$ at a flow rate of $2.0 \mathrm{~mL} /$ min (Econosil RP-18 $10 \mu \mathrm{m}$ column; $250 \times 10 \mathrm{~mm} ; 10 \mu$ particle size; Shodex refractive index detector) to yield 1 (4 $\left.\mathrm{mg}, t_{\mathrm{R}}=17.1 \mathrm{~min}\right)$ and $2\left(3 \mathrm{mg}, t_{\mathrm{R}}=18.1 \mathrm{~min}\right)$. Fraction $\mathrm{H} 13$ $(620 \mathrm{mg})$ was separated over a silica gel column (230-400 mesh, $50 \mathrm{~g}, 2 \times 25 \mathrm{~cm})$ with $\mathrm{CHCl}_{3}: \mathrm{MeOH}(150: 1)$ and purified with a RP-C $\mathrm{C}_{18}$ prep. HPLC with $75 \% \mathrm{CH}_{3} \mathrm{CN}$ to yield $3\left(4 \mathrm{mg}, t_{\mathrm{R}}=19.8 \mathrm{~min}\right)$. Fraction $\mathrm{H} 14$ (440 mg) was further separated on a silica gel (230-440 mesh, $50 \mathrm{~g}, 2 \times 25$ $\mathrm{cm})$ eluted with $n$-hexane:EtOAc $(20: 1)$ to yield four subfractions (H141-H144). Fraction H141 (50 mg) was purified with a RP-C $\mathrm{C}_{18}$ prep. HPLC with $85 \% \mathrm{CH}_{3} \mathrm{CN}$ to yield 5 (4 $\left.\mathrm{mg}, t_{\mathrm{R}}=20.2 \mathrm{~min}\right), \mathbf{6}\left(8 \mathrm{mg}, t_{\mathrm{R}}=23.1 \mathrm{~min}\right)$ and $7\left(4 \mathrm{mg} t_{\mathrm{R}}=\right.$ $29.8 \mathrm{~min})$. Fraction $\mathrm{H} 142(80 \mathrm{mg})$ was purified with a RP$\mathrm{C}_{18}$ prep. HPLC with $85 \% \mathrm{CH}_{3} \mathrm{CN}$ to yield $9\left(32 \mathrm{mg}, t_{\mathrm{R}}=\right.$ $27.2 \mathrm{~min})$. Fraction H144 (90 mg) was purified with a RP$\mathrm{C}_{18}$ prep. HPLC with $90 \% \mathrm{CH}_{3} \mathrm{CN}$ to yield $8\left(27 \mathrm{mg}, t_{\mathrm{R}}=\right.$ 
Table 2. ${ }^{13} \mathrm{C}$ NMR spectral data of compounds $\mathbf{1 - 4}$ in $\mathrm{CDCl}_{3}(125$ $\mathrm{MHz})$

\begin{tabular}{lrrrr}
\hline Position & \multicolumn{1}{c}{$\mathbf{1}$} & \multicolumn{1}{c}{$\mathbf{2}$} & $\mathbf{3}$ & $\mathbf{4}$ \\
\hline 1 & 39.4 & 39.4 & 39.4 & 39.2 \\
2 & 20.1 & 20.1 & 20.1 & 18.0 \\
3 & 38.3 & 38.3 & 38.3 & 35.6 \\
4 & 44.5 & 44.4 & 44.4 & 37.3 \\
5 & 56.5 & 56.5 & 56.5 & 49.7 \\
6 & 26.3 & 26.3 & 26.3 & 17.8 \\
7 & 38.9 & 38.9 & 38.9 & 43.4 \\
8 & 147.8 & 147.9 & 147.8 & 72.8 \\
9 & 55.8 & 55.9 & 56.2 & 57.1 \\
10 & 40.7 & 40.8 & 40.8 & 37.9 \\
11 & 21.6 & 21.4 & 21.9 & 17.3 \\
12 & 25.8 & 25.7 & 25.9 & 38.3 \\
13 & 146.3 & 146.8 & 146.3 & 36.7 \\
14 & 123.7 & 123.9 & 123.5 & 51.8 \\
15 & 107.1 & 109.1 & 107.1 & 151.8 \\
16 & 107.9 & 108.7 & 108.4 & 108.8 \\
17 & 106.7 & 106.8 & 106.9 & 24.5 \\
18 & 29.3 & 29.2 & 29.2 & 72.3 \\
19 & 182.7 & 183.0 & 182.0 & 17.7 \\
20 & 13.0 & 13.0 & 13.0 & 16.3 \\
$15-\mathrm{OCH}_{3}$ & 54.5 & 54.0 & 54.6 & \\
$16-\mathrm{OCH}_{3}$ & 53.9 & 54.6 & 53.8 & \\
\hline
\end{tabular}

$20.2 \mathrm{~min}$ ). All fractions were purified as described above. Fraction H2 (3.6 g) was separated over a RP-C ${ }_{18}$ silica gel column (230-400 mesh, $150 \mathrm{~g}, 3 \times 30 \mathrm{~cm})$ with $90 \% \mathrm{MeOH}$ to give two subfractions (H21-H22). Fraction H21 (150 mg) was purified with a silica gel prep. HPLC with $n$-hexane: EtOAc (4:1) at a flow rate of $2.0 \mathrm{~mL} / \mathrm{min}$ (Apollo Silica 5 $\mu \mathrm{m}$ column; $250 \times 10 \mathrm{~mm} ; 5 \mu$ particle size; Shodex refractive index detector) to yield compound $4\left(15 \mathrm{mg}, t_{\mathrm{R}}=15.8\right.$ $\min$ ).

Thujuoric Acid A (1): Colorless gum; $[\alpha]_{\mathrm{D}}^{25}+11.0^{\circ}(c$ $0.4, \mathrm{MeOH}) ; \mathrm{IR}(\mathrm{KBr}) v_{\max } 3078,2932,2845,1691,1641$, $1263,1164,1099,1029 \mathrm{~cm}^{-1} ;{ }^{1} \mathrm{H}$ NMR see Table $1 ;{ }^{13} \mathrm{C}$ NMR see Table 2; HRFABMS $m / z$ 401.2300 [M + Na $]^{+}$ (calcd for $\mathrm{C}_{22} \mathrm{H}_{34} \mathrm{NaO}_{5}, 401.2304$ ).

Thujuoric Acid B (2): Colorless gum; $[\alpha]_{\mathrm{D}}^{25}+5.0^{\circ}(c 0.4$, $\mathrm{MeOH}$ ); IR (KBr) $v_{\max }$ : 3079, 2928, 2844, 1693, 1645, 1266, $1163,1100,1027 \mathrm{~cm}^{-1} ;{ }^{1} \mathrm{H}$ NMR see Table $1 ;{ }^{13} \mathrm{C}$ NMR see Table 2; HRFABMS $m / z$ 401.2302 [M $+\mathrm{Na}]^{+}$ (calcd for $\mathrm{C}_{22} \mathrm{H}_{34} \mathrm{NaO}_{5}, 401.2304$ ).

Thujuoric Acid C (3): Colorless gum; $[\alpha]_{\mathrm{D}}^{25}+36.6^{\circ}(c$ $\left.0.2, \mathrm{CHCl}_{3}\right)$; IR (KBr) $v_{\max }: 3078,2932,2845,1691,1641$, 1263, 1164, 1099, $1029 \mathrm{~cm}^{-1} ;{ }^{1} \mathrm{H}$ NMR see Table $1 ;{ }^{13} \mathrm{C}$ NMR see Table 2; HRFABMS $m / z$ 401.2304 [M + Na $]^{+}$ (calcd for $\mathrm{C}_{22} \mathrm{H}_{34} \mathrm{NaO}_{5}, 401.2304$ ).

8ß,18-Dihydroxysandaracopimar-15-ene (4): Colorless oil; $[\alpha]_{\mathrm{D}}^{25}-2.0^{\circ}\left(c 0.35, \mathrm{CHCl}_{3}\right)$; IR (KBr) $v_{\max } 3424,2922$,
1635, 1444, 1385, 1034, 909, $757 \mathrm{~cm}^{-1} ;{ }^{1} \mathrm{H}$ NMR see Table $1 ;{ }^{13} \mathrm{C}$ NMR see Table 2; HREIMS $\mathrm{m} / \mathrm{z} 306.2557[\mathrm{M}]^{+}$(calcd for $\mathrm{C}_{20} \mathrm{H}_{34} \mathrm{O}_{2}, 306.2559$ ).

Cytotoxicity Assay. A SRB bioassay was used to determine the cytotoxicity of each compound isolated against four cultured human tumor cell lines. ${ }^{16}$ The assays were performed at the Korea Research Institute of Chemical Technology. The cell lines which were used were A549, SKOV-3, A498 and HCT-15. Doxorubicin was used as a positive control. The cytotoxicities of doxorubicin against the A549, SK-OV-3, A498, and HCT-15 cell lines were IC $_{50}$ $0.0007,0.1274,0.0094$, and $0.2149 \mu \mathrm{M}$, respectively.

Acknowledgments. This research was supported by the Basic Science Research Program through the National Research Foundation of Korea (NRF) funded by the Ministry of Education, Science and Technology (2012R1A5A2A28671860). We are thankful to the Korea Basic Science Institute (KBSI) for the measurements of NMR and MS spectra.

Supporting Information. The spectral data of compounds 1,2 and 4 are available on request from the corresponding author.

\section{References}

1. Sung, S. H.; Koo, K. A.; Lim, H. K.; Lee, H. S.; Cho, J. H.; Kim, H. S.; Kim, Y. C. Korean J. Pharmacognosy 1998, 29, 347.

2. Xu, G. H.; Ryoo, I. J.; Kim, Y. H.; Choo, S. J.; Yoo, I. D. Arch. Pharm. Res. 2009, 32, 275.

3. Yoon, J. S.; Koo, K. A.; Ma, C. J.; Sung, S. H.; Kim, Y. C. Nat. Pro. Sci. 2008, 14, 167.

4. Fan, S.-Y.; Zeng, H.-W.; Pei, Y.-H.; Li, L.; Ye, J.; Pan, Y.-X.; Zhang, J.-G.; Yuan, X.; Zhang, W.-D. J. Ethnopharmacol. 2012, $141,647$.

5. Kosuge, T.; Yokota, M.; Sugiyama, K.; Saito, M.; Iwata, Y.; Nakura, M.; Yamamoto, T. Chem. Pharm. Bull. 1985, 33, 5565.

6. Kim, C. S.; Choi, S. U.; Lee, K. R. Planta Med. 2012, 78, 485.

7. Yoshida, K.; Fueno, T. Bull. Chem. Soc. Jpn. 1987, 60, 229.

8. Bae, J.; Jeon, J.; Lee, Y.-J.; Lee, H.-S.; Sim, C. J.; Oh, K.-B.; Shin, J. J. Nat. Prod. 2011, 74, 1805.

9. Demarco, P. V.; Farkas, E.; Doddrell, D.; Mylari, B. L.; Wenkert, E. J. Am. Chem. Soc. 1968, 90, 5480.

10. Matsuo, A.; Uto, S.; Nakayama, M.; Hayashi, S. Tetrahedron Lett. 1976, 17, 2451.

11. Itokawa, H.; Yoshimoto, S.; Morata, H. Phytochemistry 1988, 27, 435.

12. Heymann, H.; Tezuka, Y.; Kikuchi, T.; Supriyatna, S. Chem. Pharm. Bull. 1994, 42, 138.

13. Barrero, A. F.; Alvarez-Manzaneda, E.; Lara, A. Tetrahedron Lett. 1996, 37, 3757.

14. Joseph-Nathan, P.; Santillan, R. L.; Gutiérrez, A. J. Nat. Prod. 1984, 47, 924

15. Fang, J.-M.; Chen, Y.-C.; Wang, B.-W.; Cheng, Y.-S. Phytochemistry 1996, 41, 1361 .

16. Skehan, P.; Storeng, R.; Scudiero, D.; Monks, A.; Mcmahon, J.; Vistica, D.; Warren, J. T.; Bokesch, H.; Kenney, S.; Boyd, M. R. J. Natl. Cancer Inst. 1990, 82, 1107. 